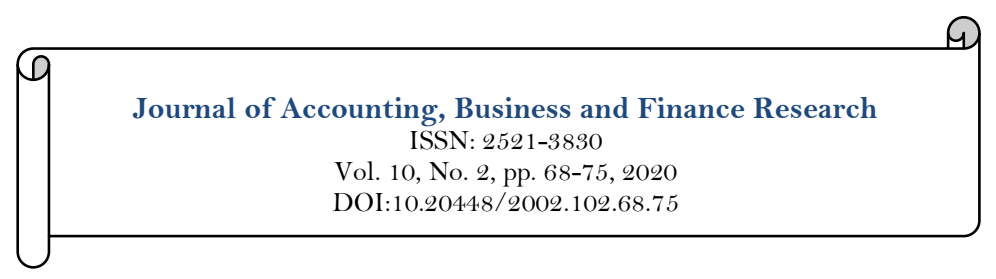

\title{
R\&D Spending and Stock Returns: Evidence from Germany
}

\section{Roland Standert}

EBS University of Business and Law, Germany. Email:roland.sta@gmail.com

\begin{tabular}{|c|c|}
\hline Abstract & \\
\hline 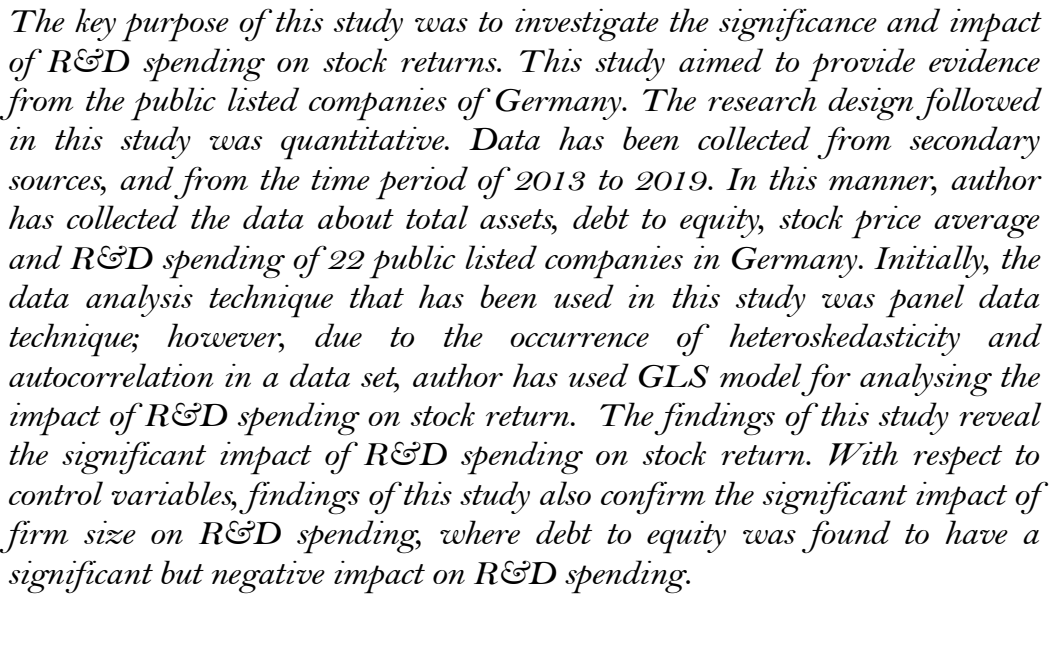 & $\begin{array}{l}\text { Keywords: } \\
\text { RE̊D spending } \\
\text { Stock returns } \\
\text { Debt to equity } \\
\text { Total assets } \\
\text { Stock price average } \\
\text { Firm size. } \\
\text { Licensed: } \\
\text { This work is licensed under a } \\
\text { Creative Commons Attribution } 4.0 \\
\text { License. } \\
\text { Publisher: } \\
\text { Scientific Publishing Institute } \\
\text { Received: } 10 \text { August } 2020 \\
\text { Revised: } 16 \text { September } 2020 \\
\text { Accepted: } 28 \text { September } 2020 \\
\text { Published: } 14 \text { October } 2020\end{array}$ \\
\hline
\end{tabular}

Funding: This study received no specific financial support.

Competing Interests: The author declares that there are no conflicts of interests regarding the publication of this paper.

\section{Introduction}

Research and development have been a key component for different organisations in the current dynamic era. This is because the technology has advanced to such an extent that innovation is crucial in order to survive and sustain in the long-run (Guo, Wang, \& Wei, 2018). Organisations that give consideration to R\&D tend to be more innovation and technologically-efficient to advance further in their domain. In this context, these tend to bring the organisation with competitive advantage in becoming market leader. Large organisations, particularly multinational organisations leverage their innovative capabilities for achieving competitive advantage (Männasoo, Hein, \& Ruubel, 2018). When the MNEs are publicly listed, the innovation capabilities also impact the stock returns of these firms as investors perceive organisations to be profitable and having high ROI if they have the potential to technologically disrupt the market (Kim \& Park, 2020). This has been the case in many real-world companies including Apple and Amazon where their successful R\&D investment and spending has led to skyrocketing their stock returns. Although the topic has been much explored in context of American and UK's listed firms, the German firms are understudied in this context. Therefore, this study seeks to fulfil the gap in literature by examining the impact of R\&D spending on stock returns with regards to top public listed German companies. 


\subsection{Aim and Objectives}

The following study aims to assess the impact of $\mathrm{R} \& \mathrm{D}$ spending on stock returns with evidence from listed companies in Germany. The study has crafted the following objectives to achieve the primary aim.

- To examine the significance of R\&D spending for multinational firms.

- To assess factors associated with R\&D spending in large companies.

- To analyse the impact of R\&D spending on stock returns in publicly listed German companies.

- To recommend strategies and measures to assess $R \& D$ spending for improving stock performance of large companies in Germany.

\subsection{Research Questions}

The main research question that this study seeks to answer is;

What is the impact of $R \Theta D$ spending on stock returns in German Companies?

The sub-questions are as follows;

- What is the significance of R\&D spending for multinational firms?

- What are factors associated with R\&D spending in large companies?

- What is the impact of $\mathrm{R} \& \mathrm{D}$ spending on stock returns in publicly listed German companies?

- What strategies and measures can be recommended to assess R\&D spending for improving stock performance of large companies in Germany?

\section{Literature Review}

According to the study of $\mathrm{Xu}$, Zhou, and $\mathrm{Du}$ (2019) R \&D investment or spending has acquired high prominence in providing great opportunities to the multinational companies (MNCs) to compete and grow in the long-run. To compete in the highly competitive and globalised business environment, multinational companies (MNCs) are continually attempting to enhance their profit through spending in R\&D where they expect long-term profitability and return on investment. With regard to it, Ehie and Olibe (2010) stated that spending in $\mathrm{R} \& \mathrm{D}$ enable MNCs to augment their asset activity in order to attain additional settings over their previous ones and secure their long-term competitive advantage. In the support, Holmes, Li, Hitt, DeGhetto, and Sutton (2016) stated that the investment in R \&D also allow MNCs to contribute actively in the transfer of old technologies to the new and innovative technologies in the host country as a way of absorbing local knowledge and develop specific competitive advantage for the business.

Recent studies suggest that $\mathrm{R} \& \mathrm{D}$ spending by multinational firms is considered to be an important or effective approach to the innovation. Lin, Wu, Chang, Wang, and Lee (2012) stated that the R\&D spending provide opportunities to multinational firms for increasing higher level of literacy and financial development in order to innovate and meet the consumer demands, along with provide the skills essential for the workforce to become innovative and creative in the highly competitive business environment. In this regard, (Duqi, Mirti, \& Torluccio, 2011) stated that the spending in R\&D is essential for improving not only firm's market value but also significant for increasing stock return for the multinational firms in local as well as in the international business market. Moreover, Brem and Wolfram (2014) stated that the R\&D investments make MNCs able to improve their research and development ability regarding their goods and offerings and develop new products and services. A study of Nieto and Rodríguez (2011) support this statement and stated that $\mathrm{R} \& \mathrm{D}$ spending by MNCs contribute significantly in stimulating innovative and creativity in business in terms of production, costs reduction, and quality improvement of companies' products and offerings.

Furthermore, Cusumano (2010) stated that several companies have invested huge amount in R \&D in order to develop new products and technologies and remain competitive in the marketplace such as Amazon, Volkswagen, Alphabet, Intel and Samsung. These companies spent huge amount in $\mathrm{R} \& \mathrm{D}$ in order to increase their market value and stock returns. The leading German company for $\mathrm{R} \& \mathrm{D}$ spending is carmaker Volkswagen. Gershman (2012) stated that the Volkswagen spends approximately 13.1 billion euros on R \&D per year and this spending ranked Volkswagen number one German company that attain high stock returns as a result of their high spending on $\mathrm{R} \& \mathrm{D}$. On the other hand, Hernández et al. (2014) stated that Diamler, BMW, Robert Bosch, Bayer, and Siemens are major German companies that are leading companies for R\&D spending across the globe. All these invest on $\mathrm{R} \& \mathrm{D}$ in order to introduce new and innovative products and services to the marketplace and add value to the companies' bottom line. In the support, Hirshleifer, Hsu, and $\mathrm{Li}$ (2013) stated that there is a significant association between R\&D spending and subsequent stock returns. As stated by Başgoze and Sayin (2013) the estimated R\&D investment is not likely to be completely reflected contemporaneously in stock prices, as the spending on $\mathrm{R} \& \mathrm{D}$ is correlated with subsequent stock returns. These findings are in accordance with the findings of Peterson and Jeong (2010) which stated that R\&D investment is significant for absorbing book-to-market effect, leading to cause significant stock returns and develop market value for the companies. Moreover, Donelson and Resutek (2012) stated that investment on $\mathrm{R} \& \mathrm{D}$ allow MNCs to earn higher stock returns as it allows firms to control the book-to-market ratio. It asserts that R\&D investment has positive impact on stock returns. 
There is a large body of evidence that have examined the factors of $\mathrm{R} \& \mathrm{D}$ influencing the association between R\&D spending and stock returns. Wang and Wang (2012) stated that firm size is an essential factor that plays essential role in developing knowledge. It also emphasised that large firms can generate large share of technological advantage for the society as compared to small firms. However, Bronzini and Piselli (2016) argued with this statement and stated that small firms also make large investments on $\mathrm{R} \& \mathrm{D}$ in order to innovate or produce new products and services. It asserts that firm size can influence R\&D spending, leading to improve stock returns for both small and large companies.

Furthermore, Hall and Lerner (2010) stated that expected return on R\&D investment also influence significant on $\mathrm{R} \& \mathrm{D}$ in large companies. A firm considers past results and returns on $\mathrm{R} \& \mathrm{D}$ spending before making present and future $\mathrm{R} \& \mathrm{D}$ investments. Variations in expected return on $\mathrm{R} \& \mathrm{D}$ investments influence $\mathrm{R} \& \mathrm{D}$ activities of firms in association with profitability, capacities of firm, and attitudes towards investment on $\mathrm{R} \& \mathrm{D}$. In addition, He and Wintoki (2016) stated that cash flow is another major factor that can affect R\&D spending in large companies. The availability of cash flow allows firms to spend amount on R\&D activities and improve the stock return of high-tech sector or public organizations.

Moreover, the association between internal funding and R\&D spending has extensively been studied in the literature. Internal funding allows firms to make investment on $\mathrm{R} \& \mathrm{D}$ activities as well as enable firms to raise external funds for reducing transaction costs and risks associated with the financing of R\&D spending (Berchicci, 2013). Additionally, Coad and Rao (2010) stated that firm's sales growth is also a major associated $\mathrm{R} \& \mathrm{D}$ spending in large companies. An increase in net sales profit results in an increase of R\&D investment. Other factors that can affect R\&D investment in large companies may include risk, government subsidy, intangible assets, outward orientation, etc.

The impact of R\&D investment on stock returns is extensively discussed in the literature. For example, a study of Artz, Norman, Hatfield, and Cardinal (2010) highlighted that R\&D investment allows firms to improve their organizational and technological capabilities, leading to increase their return on stock. In the support, Shapiro and Hanouna (2019) stated that risk associated with R\&D spending promotes the conception that R\&D spending is significantly correlated with financial performance and stock returns of multinational firms as the actual controller and shareholders are committed more on R\&D resources and activities and take less risk, which hence essentially influence other shareholders and funders to spend on R\&D activities. It is also stated by Zhang, Ding, and Ke (2019) that large shareholders are required to prioritise long-term R\&D investments in order to increase the stability of publicly listed firms. Stable ownership in large companies can tightly regulate and control investment activities, which is essential for making investment in new and innovative technologies.

According to a study of Mazzucato and Tancioni (2013) stock prices and returns are significantly associated with $\mathrm{R} \& \mathrm{D}$ expenditures. This study highlighted that investors make adjustment to the valuation in order to attain long-term profits from R\&D investments and avoid potential mispricing. A study of Lahtinen (2020) argued with these findings and stated that there is a weak association between R\&D investment and stock returns. However, a study of $\mathrm{Gu}$ (2016) suggested that R\&D spending is associated positively with returns, specifically for the stocks with high R\&D investment to market ratio. A study of Li (2011) found evidence of significant positive association of long-term stock returns with R\&D spending due to unexpected enhancement in R\&D investment.

However, Hall, Mairesse, and Mohnen (2010) stated that investors underestimate the benefits of spending on $\mathrm{R} \& \mathrm{D}$ and thus the market is slow in integrating the benefits of $\mathrm{R} \& \mathrm{D}$ spending in improving stock returns of publicly listed multinational enterprises. There is also evidence available which emphasised that shareholders experience a significant stock returns due to spending on R\&D during a five-year period. The findings of the study of Ciftci and Cready (2011) suggest that R\&D spending is positively correlated with stock returns. This may be due to the asymmetric knowledge regarding the R\&D spending that result into a significant positive correlation between $\mathrm{R} \& \mathrm{D}$ investment and stock returns for large companies.

Currim, Lim, and Kim (2012) stated that intangible assets and available cash flow allow firms to increase return on stock through spending on R\&D activities. Lin. (2012) further stated that R\&D investment to sales has negative significant impact on stock returns, however, R\&D spending to market value has positive significant impact on stock returns. The findings of the available studies and literature provided contradicted results as some studies shows positive effect of $\mathrm{R} \& \mathrm{D}$ investment on stock return and some studies shows negative effect of $\mathrm{R} \& \mathrm{D}$ investment on stock return. Thus, in this perspective, the hypothesis of the research intended to be tested is:

$H_{1}: R \Xi D$ spending has a positive significant influence on stock returns.

$H_{2}: R \Xi D$ spending has a negative significant influence on stock returns.

The association between $\mathrm{R} \& \mathrm{D}$ spending and stock returns can be underpinned with two important theories, including a behavioural theory of R\&D spending and innovations and Schumpeterian growth theory. Lee and $\mathrm{Wu}$ (2016) stated that the behavioural theory of R\&D spending and innovations asserts that the expenses of research and development are increased when excess resources cause slack search and problematic research. This theory also asserts that innovations can be generated through R\&D spending as well as improve financial performance of the organisations. In addition, the behavioural theory of R\&D spending 
offers opportunity to the firms to improve their financial performing and stability through launching innovative ideas and compete differentially in the competitive marketplace.

It is stated by Bromiley and Washburn (2011) that decision to make investment on R\&D is the decisionmaking phase of behavioural theory of $\mathrm{R} \& \mathrm{D}$ spending and innovations that contribute essentially in enhancement of firm's financial performance and offers opportunity to make notable returns and profitability for the business. This theoretical framework emphasises the importance of spending R\&D for stimulating innovation and creativity in the business process in order to improve productivity and stock returns. The behavioural theory of $\mathrm{R} \& \mathrm{D}$ spending and innovation also emphasises that the organisational procedures of search, performance evaluation, decision-making, and offering of R\&D spending influence significantly on the financial performance of a firm. Firms with sufficient resources engaged in R\&D activities can efficiently innovative new products and technology in the market and subsequently improve their financial performance and returns on stocks.

Another theory that underpins the impact of $\mathrm{R} \& \mathrm{D}$ spending on stock returns is the Schumpeterian growth theory. Bittencourt (2012) stated that the Schumpeterian growth theory asserts that development innovations and entrepreneur have paramount role in the process of financial development. As per the theory of Schumpeter, the production process is marked by a coordination of innovative productive forces. In this regard, Aghion, Akcigit, and Howitt (2014) stated that the Schumpeterian growth theory emphasises that financial growth and development is driven through innovation governed through a spending on research and development activities within the organisational setting. It is also stated by Aghion and Festré (2017) that Schumpeterian growth theory asserts that spending on R\&D policy support the improvement of firm's economic growth over the long run. This reflects that R\&D significantly influences economic growth and stock returns in large companies.

The technology-push theory of R\&D investment also emphasises the association between R\&D and stock returns. This theory asserts that profit-maximising R\&D spending is significantly associated with return on investment or stock and emphasises that technology and innovation push influence large companies to make investments on R\&D and improve their economic performance through competing innovatively in the business environment. With regard to it, Ghisetti and Pontoni (2015) stated that technology-push theory of $\mathrm{R} \& \mathrm{D}$ highlighted that technology push development in $\mathrm{R} \& \mathrm{D}$ and drives innovation in new product and services in order to make significant stock returns and improve net profit.

\section{Methodology}

In this study, researcher has used the quantitative research design to accomplish the key objectives. According to Bloomfield and Fisher (2019) quantitative research design is associated with systematic underpinnings, which involves the use of statistical tools and the use of statistical analysis technique for obtaining the key aim of the study. Since, the nature of this study requires more factual data to determine the association between $\mathrm{R} \& \mathrm{D}$ spending and stock returns, therefore the use of quantitative research design was considered as more suitable approach for this study. In this regard, this study is carried out on the basis of positivism philosophy, which is backed by the notion that only factual knowledge obtained through observation is considered to be trustworthy, thus such knowledge helps in making the better understanding of research phenomena (Ryan, 2018). Hence, based on the nature of this study, researcher has followed positivism research philosophy in this study.

The research approach followed in this study was deductive approach, which is mainly due to the fact that this approach is considered to be more suitable for quantitative study. The common difference between deductive and inductive approach is linked with the fact that inductive approach emphasises on generating new theory, whereas deductive approach deals with testing existing theory (Woiceshyn \& Daellenbach, 2018). Since, the primary goal of this study was to test the existing theory by establishing the hypothesis at the beginning of the study, therefore researcher has opted for deductive research approach. With respect to the data collection method, the use of secondary sources has been made in this study. The key justification behind using secondary data in this study is associated with the type of research questions needed to be answered in this study, as it requires the extensive amount of data collection which would not have been possible with the use of primary methods of data collection. Therefore, researcher has gathered the most relevant data from different authentic secondary sources like websites, World Bank's reports, and company's reports. Moreover, researcher has gathered 7 years of data from the time period of 2013 to 2019. The data of 22 public listed companies in Germany has been gathered with respect to different variables including debt to equity, total assets, stock price average, and R\&D. The collection of data on these variables allows the researcher to evaluate the association between R\&D spending and stock returns.

The use of appropriate data analysis technique is considered as another important aspect of the study. The selection is highly depending on the type of data that is needed to be analysed. Therefore, researcher in this study has used GLS model to analyse the secondary quantitative data. According to Castro and Ariño (2016) GLS model is one of the most widely used statistical method for assessing the unknown variable in a linear regression model in a situation where there is a certain level of correlation exist among the residuals in regression model. The use GLS model technique helps the researcher to better examine the association between R\&D spending and stock returns of Germany's public listed companies. 


\section{Results}

In preceding chapter, researcher highlights all the key approaches and methods that are used to achieve the main objectives of this study. This section is devoted to present the key findings of the study through analysing secondary quantitative data.

4.1. Descriptive Statistics

Descriptive statistics is viewed as one of the most effective and widely used statistical techniques for interpreting the data in a more detailed manner. According to Bickel and Lehmann (2012) descriptive statistics is useful technique for analysing the statistical characteristics of all the variables included in the model. Descriptive statistics highlight the values of number of observations, mean, range, and standard deviation. The explanation provided in inferential statistics is not just restricted to data but it also provides the conclusion. However, in descriptive statistics, researcher only emphasise on what data shows.

\begin{tabular}{c|c|c|c|c|c}
\multicolumn{7}{c}{ Table-1. Descriptive statistics. } \\
\hline Variable & Obs & Mean & Std. Dev. & Min & Max \\
\hline Total Assets & 154 & 118000000 & 189000000 & 71000 & 1010000000 \\
\hline Debt to Equity & 154 & 1.076623 & .219863 & 0 & 9.54 \\
\hline RD & 154 & 2070821 & 1231895 & 124000 & 6554000 \\
\hline Ret & 154 & 90.82092 & 144.7812 & 6.754363 & 796.9761 \\
\hline
\end{tabular}

In this study, the variable of debt to equity is taken as a metric for assessing the company's leverage. Based on the figures presented in Table 1, the total number of observations taken for each variable is 154. As per the mean value highlighted in Table 1, the average total assets of all the 22 public listed companies in Germany is computed at 118000000 . On the other hand, as per the values highlighted in Table 1, the variable of total asset will deviate from 189000000 . Moreover, the findings of descriptive statistics reveal that all 22 public listed companies investigated in this study are found to have an average debt to equity of 1.076623 . The standard deviation value of debt to equity shows that debt to equity of all the investigated company will deviate from 0.219863. Based on the total 154 observations, the average value of R\&D spending is figured at 2070821 , whereas average stock returns were computed at 90.82092 .

Initially, the use of fixed and random effect model was made to examine the impact of R\&D spending on stock returns; however, during the diagnostic test, researcher has found certain issues pertaining to the existence of heteroscedasticity and xtserial in a data set, as mentioned in Tables 2 and 3. Therefore, GLS model has been applied to determine the impact of R\&D spending on stock returns.

Table-2. Heteroskedasticity.

\begin{tabular}{c|c}
\hline Test & Statistics \\
\hline Chi2 $(22)$ & 66061.51 \\
\hline \multicolumn{2}{c}{ Table-3. Xtserial. } \\
\hline Prob. $>$ chi2s & Statistics \\
\hline Test & 9.327 \\
\hline F $(1,21)$ & 0.00600 \\
\hline Prob. $>\mathrm{F}$ &
\end{tabular}

\subsection{GLS Model}

The aforementioned Table 4 highlights the results of GLS model. In this study, the variable of R\&D expenses was taken as an independent variable, whereas debt to equity and firm size was taken as the control variables. The influence of all these variables has been examined on return on stock, which was considered as a dependent variable of this study. As per the results presented in Table 4, there is a significant impact of R\&D expenses on stock returns, as P-value is computed to be 0.000 . In this regard, the value coefficient depicts that a unit change in $\mathrm{R} \& \mathrm{D}$ is likely to change stock return by 20.34 units. On the other hand, both the control variables are also found to have a significant impact on stock returns, as p-value of both debt to equity and firm size is computed at 0.000 . Moreover, the coefficient value of debt to equity depicts that a unit change in debt to equity will bring a negative change on stock return by -4.316054 . However, as per the results of GLS model, a unit change in firm size is likely to make a positive change on stock return by 68.87466 .

\section{Discussion}

The significance of $\mathrm{R} \& \mathrm{D}$ spending for stock returns has been well recognised in most of the previous studies (Cusumano, 2010; Duqi et al., 2011; Nieto \& Rodríguez, 2011) however, there was a lack of evidence in the context of Germany. Therefore, the key rationale of this study has been to examine the influence of R\&D spending on stock returns of public listed companies in Germany. The results presented in the earlier section have signified the importance of R\&D for stock returns. The findings of GLS confirmed the significant impact of R\&D spending on stock returns. This implies that higher spending on R\&D helps the public listed 
companies of Germany in raising their stock returns. This is also found to be consistent with the study of Holmes et al. (2016) according to which R\&D spending not just enhance market value of the firm, but it also plays a crucial role in increasing stock returns. The primary findings of this study also confirm the significant impact of control variables on stock returns. However, the control variable debt to equity is found to have a significant but negative impact on stock return, whereas firms' size is found to have a significant and positive impact on stock return.

Table-4. GLS Model.

\begin{tabular}{|c|c|c|c|c|c|c|}
\hline Estimated covariance & 22 & & & & Number of obs & 132 \\
\hline Estimated autocorrelations & 22 & & & & Number of groups & 22 \\
\hline Estimated coefficients & 4 & & & & Time periods & 6 \\
\hline & & & & & Wald chi2(4) & 183.57 \\
\hline & & & & & Prob > chi 2 & 0.000 \\
\hline Ret & Coef. & Std. & $\mathrm{Z}$ & $\mathrm{P}>|\mathrm{z}|$ & \multicolumn{2}{|c|}{ [95\% Conf. interval] } \\
\hline RDExp & 20.34819 & 4.999727 & 4.07 & 0.000 & 10.5489 & 30.14747 \\
\hline Debt to Equity & -4.316054 & .9762448 & -4.42 & 0.000 & -6.229459 & -2.40265 \\
\hline Firm size & 68.87466 & 7.80986 & 8.82 & 0.000 & 53.56762 & 84.1817 \\
\hline _cons & -600.3517 & 56.58763 & -10.61 & 0.000 & -711.2615 & -489.442 \\
\hline
\end{tabular}

\section{Conclusion}

The primary goal of this study has been to study the impact of R\&D spending on stock returns. This study aimed to provide evidence from the public listed companies from Germany. On the basis of the study nature, researcher has followed quantitative research design, and gathered secondary data of 22 public listed companies in Germany. Moreover, the 7 years of data has been collected from the time period of 2013 to 2019. In this regard, the data has been gathered with respect to different variables, which include total assets, debt to equity, stock price average, and R\&D spending. The variable of R\&D spending was taken as independent variable, whereas debt to equity and firm size was considered as control variables. The impact of all these variables was determined on stock return, which was considered as a dependent variable of the study. The overall outcomes of this research reveal the significant impact of R\&D spending on stock returns of all the investigated companies. Moreover, the findings of this study also confirm the significant and positive impact of firm size on stock returns. However, the variable of debt to equity is found to have a significant but negative impact on stock returns.

\section{Recommendations}

The following recommendations are proposed on the basis of the major outcomes of this study:

- Companies are advised to take important steps towards eliminating the additional cost that is linked with R\&D spending. Besides company’s approach to increase R\&D spending, it is also crucial to drive efficiency by cutting additional cost. Therefore, to make more efficient spending on R\&D, companies can consider following staffing models, and increasing automation and analytics.

- It has also been recommended to the companies to embrace technology like machine learning. The use of such technologies can allow the company to enhance their $\mathrm{R} \& \mathrm{D}$ decision making

- The process of R\&D is considered as more complicated; thus, companies are required to enhance their technical and analytical skills. Hence, if firms want to attain the potential of big data and to take advantages from their spending on $\mathrm{R} \& \mathrm{D}$, then companies are required to hire the most competent employees with proper data science skills.

\section{Future Research}

The limited scope of this research has been one of the key limitations of the study, as this study only provides the evidence from public listed companies of Germany. Therefore, it has been recommended to the future researchers to broaden the scope of this study by adding more countries into the research investigation. On the other hand, absence of qualitative data has been another major limitation of this study, as this study was entirely based on quantitative research design. Hence, future researchers are advised to carry out the same study with mixed research design to provide more conclusive results.

\section{References}

Aghion, P., Akcigit, U., \& Howitt, P. (2014). What do we learn from Schumpeterian growth theory? In Handbook of economic growth (Vol. 2): Elsevier.

Aghion, P., \& Festré, A. (2017). Schumpeterian growth theory, Schumpeter, and growth policy design. Journal of Evolutionary Economics, 27(1), 25-42. Available at: https://doi.org/10.1007/s00191-016-0465-5.

Artz, K. W., Norman, P. M., Hatfield, D. E., \& Cardinal, L. B. (2010). A longitudinal study of the impact of R\&D, patents, and product innovation on firm performance. Journal of Product Innovation Management, 27(5), 725-740. Available at: https://doi.org/10.1111/j.1540-5885.2010.00747.x. 
Başgoze, P., \& Sayin, C. (2013). The effect of R\&D expenditure (investments) on firm value: Case of Istanbul stock exchange. Journal of Business Economics and Finance, 2(3), 5-12.

Berchicci, L. (2013). Towards an open R\&D system: Internal R\&D investment, external knowledge acquisition and innovative performance. Research Policy, 42(1), 117-127. Available at: https://doi.org/10.1016/j.respol.2012.04.017.

Bickel, P. J., \& Lehmann, E. L. (2012). Descriptive statistics for nonparametric models I. Introduction. In Selected Works of EL Lehmann (pp. 465-471). Boston, MA: Springer.

Bittencourt, M. (2012). Financial development and economic growth in Latin America: Is Schumpeter right? Journal of Policy Modeling, 34(3), 341-355. Available at: https://doi.org/10.1016/j.jpolmod.2012.01.012.

Bloomfield, J., \& Fisher, M. J. (2019). Quantitative research design. Journal of the Australasian Rehabilitation Nurses Association, 22(2), 27.

Brem, A., \& Wolfram, P. (2014). Research and development from the bottom up-introduction of terminologies for new product development in emerging markets. Journal of Innovation and Entrepreneurship, 3(1), 1-22.

Bromiley, P., \& Washburn, M. (2011). Cost reduction vs innovative search in R\&D. Journal of Strategy and Management.

Bronzini, R., \& Piselli, P. (2016). The impact of R\&D subsidies on firm innovation. Research Policy, 45(2), 442-457. Available at: https://doi.org/10.1016/j.respol.2015.10.008.

Castro, R. G., \& Ariño, M. A. (2016). A general approach to panel data set-theoretic research. Journal of Advances in Management Sciences \& Information Systems, 2, 63-76.

Ciftci, M., \& Cready, W. M. (2011). Scale effects of R\&D as reflected in earnings and returns. Journal of Accounting and Economics, 52(1), 62-80. Available at: https://doi.org/10.1016/j.jacceco.2011.02.003

Coad, A., \& Rao, R. (2010). Firm growth and R\&D expenditure. Economics of Innovation and Ner Technology, 19(2), 127-145.

Currim, I. S., Lim, J., \& Kim, J. W. (2012). You get what you pay for: The effect of top executives' compensation on advertising and R\&D spending decisions and stock market return. Journal of Marketing, 76(5), 33-48. Available at: https://doi.org/10.1509/jm.11.0225.

Cusumano, M. A. (2010). Staying power: Six enduring principles for managing strategy and innovation in an uncertain world (lessons from Microsoft, Apple, Intel, Google, Toyota and more): Oxford University Press.

Donelson, D. C., \& Resutek, R. J. (2012). The effect of R\&D on future returns and earnings forecasts. Review of Accounting Studies, 17(4), 848-876. Available at: https://doi.org/10.1007/s11142-011-9179-y.

Duqi, A., Mirti, R., \& Torluccio, G. (2011). An analysis of the R\&D effect on stock returns for European listed firms. European Journal of Scientific Research, 58(4), 482-496.

Ehie, I. C., \& Olibe, K. (2010). The effect of R\&D investment on firm value: An examination of US manufacturing and service industries. International Journal of Production Economics, 128(1), 127-135. Available at: https://doi.org/10.1016/j.ijpe.2010.06.005.

Gershman, M. (2012). New challenges for STI policy from the internationalization of R\&D: The case of Russian-German R\&D cooperation. Higher School of Economics Research Paper No. BRP, 2.

Ghisetti, C., \& Pontoni, F. (2015). Investigating policy and R\&D effects on environmental innovation: A meta-analysis. Ecological Economics, 118, 57-66. Available at: https://doi.org/10.1016/j.ecolecon.2015.07.009.

Gu, L. (2016). Product market competition, R\&D investment, and stock returns. Journal of Financial Economics, 119(2), 441-455. Available at: https://doi.org/10.1016/j.jfineco.2015.09.008.

Guo, B., Wang, J., \& Wei, S. X. (2018). R\&D spending, strategic position and firm performance. Frontiers of Business Research in China, 12(1), 1-19. Available at: https://doi.org/10.1186/s11782-018-0037-7.

Hall, B. H., \& Lerner, J. (2010). The financing of R\&D and innovation. In Handbook of the Economics of Innovation (Vol. 1 , pp. 609-639). North-Holland.

Hall, B. H., Mairesse, J., \& Mohnen, P. (2010). Measuring the returns to R\&D. In Handbook of the Economics of Innovation (Vol. 2, pp. 1033-1082). North-Holland.

He, Z., \& Wintoki, M. B. (2016). The cost of innovation: R\&D and high cash holdings in US firms. Journal of Corporate Finance, 41, 280-303. Available at: https://doi.org/10.1016/j.jcorpfin.2016.10.006.

Hernández, H., Tuebke, A., Hervás, F., Vezzani, A., Dosso, M., Amoroso, S., \& Grassano, N. (2014). The 2014 EU industrial R\&D investment scoreboard. EU R\&D Scoreboard Report.

Hirshleifer, D., Hsu, P.-H., \& Li, D. (2013). Innovative efficiency and stock returns. Journal of Financial Economics, 107(3), 632-654. Available at: https://doi.org/10.1016/j.jfineco.2012.09.011.

Holmes, J. R. M., Li, H., Hitt, M. A., DeGhetto, K., \& Sutton, T. (2016). The effects of location and MNC attributes on MNCs' establishment of foreign R\&D centers: Evidence from China. Long Range Planning, 49(5), 594-613.

Kim, Y. S., \& Park, K. J. (2020). R\&D spending and stock returns: Evidence from South Korea. Asian Economic and Financial Review, 1O(7), 744-757. Available at: https://doi.org/10.18488/journal.aefr.2020.107.744.757.

Lahtinen, H. M. (2020). REंD spending, stock market valuation $\Theta^{2}$ profitability: The effect of mergers and acquisitions in technologyintensive industries. Master's Degree Thesis,Master's Degree Program in Finance, University of Vaasa, Finland.

Lee, C. L., \& Wu, H. C. (2016). How do slack resources affect the relationship between R\&D expenditures and firm performance? REDD Management, 46(S3), 958-978. Available at: https://doi.org/10.1111/radm.12141.

Li, D. (2011). Financial constraints, R\&D investment, and stock returns. The Review of Financial Studies, 24(9), $2974-3007$.

Lin, C., Wu, Y.-J., Chang, C., Wang, W., \& Lee, C.-Y. (2012). The alliance innovation performance of R\&D alliances-the absorptive capacity perspective. Technovation, 32(5), 282-292. Available at: https://doi.org/10.1016/j.technovation.2012.01.004.

Lin., X. (2012). Endogenous technological progress and the cross-section of stock returns. Journal of Financial Economics, 103(2), 411-427. Available at: https://doi.org/10.1016/j.jfineco.2011.08.013.

Männasoo, K., Hein, H., \& Ruubel, R. (2018). The contributions of human capital, R\&D spending and convergence to total factor productivity growth. Regional Studies, 52(12), 1598-1611. Available at: https://doi.org/10.1080/00343404.2018.1445848. 
Mazzucato, M., \& Tancioni, M. (2013). REDD, patents and stock return volatility. In long term economic development. Springer: Berlin, Heidelberg.

Nieto, M. J., \& Rodríguez, A. (2011). Offshoring of R\&D: Looking abroad to improve innovation performance. Journal of International Business Studies, 42(3), 345-361. Available at: https://doi.org/10.1057/jibs.2010.59.

Peterson, R. A., \& Jeong, J. (2010). Exploring the impact of advertising and R\&D expenditures on corporate brand value and firm-level financial performance. Journal of the Academy of Marketing Science, 38(6), 677-690. Available at: https://doi.org/10.1007/s11747-010-0188-3.

Ryan, G. (2018). Introduction to positivism, interpretivism and critical theory. Nurse Researcher, 25(4), 41-49.

Shapiro, A. C., \& Hanouna, P. (2019). Multinational financial management: John Wiley \& Sons.

Wang, Z., \& Wang, N. (2012). Knowledge sharing, innovation and firm performance. Expert Systems with Applications, 39(10), 8899-8908.

Woiceshyn, J., \& Daellenbach, U. (2018). Evaluating inductive vs deductive research in management studies: Implications for authors, editors, and reviewers. Qualitative Research in Organizations and Management: An International Journal, 13(2), 183-195. Available at: https://doi.org/10.1108/qrom-06-2017-1538.

Xu, D., Zhou, K. Z., \& Du, F. (2019). Deviant versus aspirational risk taking: The effects of performance feedback on bribery expenditure and R\&D intensity. Academy of Management Journal, 62(4), 1226-1251. Available at: https://doi.org/10.5465/amj.2016.0749.

Zhang, H., Ding, D., \& Ke, L. (2019). The effect of R\&D input and financial agglomeration on the growth private enterprises: Evidence from Chinese manufacturing industry. Emerging Markets Finance and Trade, 55(10), 22982313. Available at: https://doi.org/10.1080/1540496x.2018.1526668. 